\title{
The brown trout Salmo trutta L. populations in the river Lima catchment
}

\author{
C.F.Q. Maia and A.C.N. Valente
}

Departamento de Zoologia e Antropologia, Faculdade de Ciências do Porto. Centro de Estudos de Ciência Animal, ICETA/UP, Praça Gomes Teixeira, 4050 PORTO, PORTUGAL

\begin{abstract}
All the Lima tributaries are considered to be salmonid Rivers. As a result of intense angling pressure, some tributaries are subject to special angling regulations. However, a correct management of populations of brown trout (Salmo trutta) needs to be based on knowledge of these populations. The populations of six tributaries (Vade, Estorãos, Trovela, Labruja, Tamente and Froufe) have been characterised. From September 1995, electrofishing surveys have been conducted every three months in the Rivers Vade (four sites), Estorãos (two sites) and Trovela (one site). One annual sample has been obtained from Labruja, Tamente and Froufe. Brown trout is the only fish species present in all sampling sites, representing more than $50 \%$ of total catch in the upstream sites. Brown trout densities varied along the River length and also within the tributaries sampled. Mean values were always greater than $10 \mathrm{ind} / 100 \mathrm{~m}^{2}$, but in some sites more than $20 \mathrm{ind} / 100 \mathrm{~m}^{2}$ were found. Mean trout biomass was $285.5 \mathrm{gFW} / 100 \mathrm{~m}^{2}$, ranging from 23.04 to $727.04 \mathrm{gFW} / 100 \mathrm{~m}^{2}$. Population age-structure showed within-site variation, i.e. $0^{+}$and $1^{+}$fish were dominant at most sites, although $5^{+}$to $7^{+}$trout were also captured. The improve conservation efforts of the brown trout needs of more data, related to angling pressure (e.g. number of angler visits and catches) and a more effective control of this.
\end{abstract}

Key words: Salmo trutta, density, biomass, growth, River Lima, Portugal.

\section{RESUMEN}

Todos los afluentes del río Lima están considerados como salmoneros. Como resultado de un intensa pesca con caña algunos de los afluentes están sometidos a regulaciones especiales de pesca. NO obstante, la correcta gestión de las poblaciones de trucha, Salmo trutta, solo serán posibles si se basan en el conocimiento de estas poblaciones. Desde Setiembre de 1995, se han caracterizado las poblaciones de seis afluentes (Vade, Estoraos, Trovela, Labruja, Tamente y Froufe). Trimestralmente se han realizado una serie de muestreos mediante electropesca en los rios Vade (cuatro estaciones), Estoraos (dos estaciones) y Trovela (una estación); mientras que en los demás afluentes se ha realizado un muestreo. La trucha es la única especie presente en todos las estaciones, representando más del $50 \%$ de las capturas totales en los tramos de río de cabecera. Las densidades de truch a varían a lo largo del río así como en los tributarios muestreados, con valores medios siempre superiores a $10 \mathrm{ind} / 100 \mathrm{~m}^{2}$, pero en algunos puntos se han hallado densidades superiores a $20 \mathrm{ind} / 100 \mathrm{~m}^{2}$. Los valores medios de biomasa de truchas fueron de $285.5 \mathrm{gPF} / 100 \mathrm{~m}^{2}$ (oscilando entre 23.04 a $727.04 \mathrm{gPF} / \mathrm{m}^{2}$ ). La estructura de edades de las poblaciones también muestra variaciones entre estaciones; los peces de $0^{+}$y $1^{+}$son dominantes en la mayoría de las estaciones, pero también se capturaron truchas de $5^{+}$a $7^{+}$. La conservación de las poblaciones de trucha requiere más datos sobre la presión de la pesca con caña (número de pescadores y capturas) y un control más efectivo.

Palabras clave: Salmo trutta, densidad, biomasa, crecimiento, río Lima, Portugal 


\section{INTRODUCTION}

The brown trout (Salmo trutta) is a native salmonid in Portuguese Rivers and is present in most River basins in the North.

The River Lima brown-trout populations support a thriving sports fishery. Intense angling pressure has led to the implementation of special regulations and to a considerable re-stocking effort (Ramos, 1982; Maia-Mendes, 1997). However, the lack of a monitoring programme precludes the evaluation of the efficiency of the management plan, which has been implemented. Thus, knowledge is scarce about brown trout populations and of the recreational fishery in basin of River Lima.

The project aims to evaluate the current status of brown trout populations and the effect angling is having on these.

\section{STUDY AREA}

The River Lima is a salmonid River in the Northwest of Portugal. The study was carried out in six of its tributaries, i.e. Rivers Vade (4 sites),
Estorãos (2 sites), Trovela (1 site), Labruja (1 site), Froufe (1 site) and Tamente (1 site) (Figure 1). All tributaries are similar in length (10-15 $\mathrm{km}$ ), source altitude (300 to $500 \mathrm{~m}$ ) and morphodynamic features. Froufe and Tamente are upstream of the Touvedo dam, situated on the main River, while the rest are located downstream of the dam. The basin of River Lima is granitic. Climate is oceanic, with typically large inter-annual variability in meteorological conditions. The tributaries have a high slope in the upper reaches, with abundance of riffle habitats and sparse aquatic vegetation. The riverside has trees. In downstream sites the slope decreases, pool habitats predominate over riffle areas, substrate is more diverse and riparian and aquatic vegetation becomes abundant. Surrounding areas in these reaches are largely agricultural.

\section{MATERIAL AND METHODS}

Electrofishing surveys have been conducted every three months from September 1995, of the Rivers Vade (three sites, V1 to V3, plus an additional site, V4, from February 1997), River

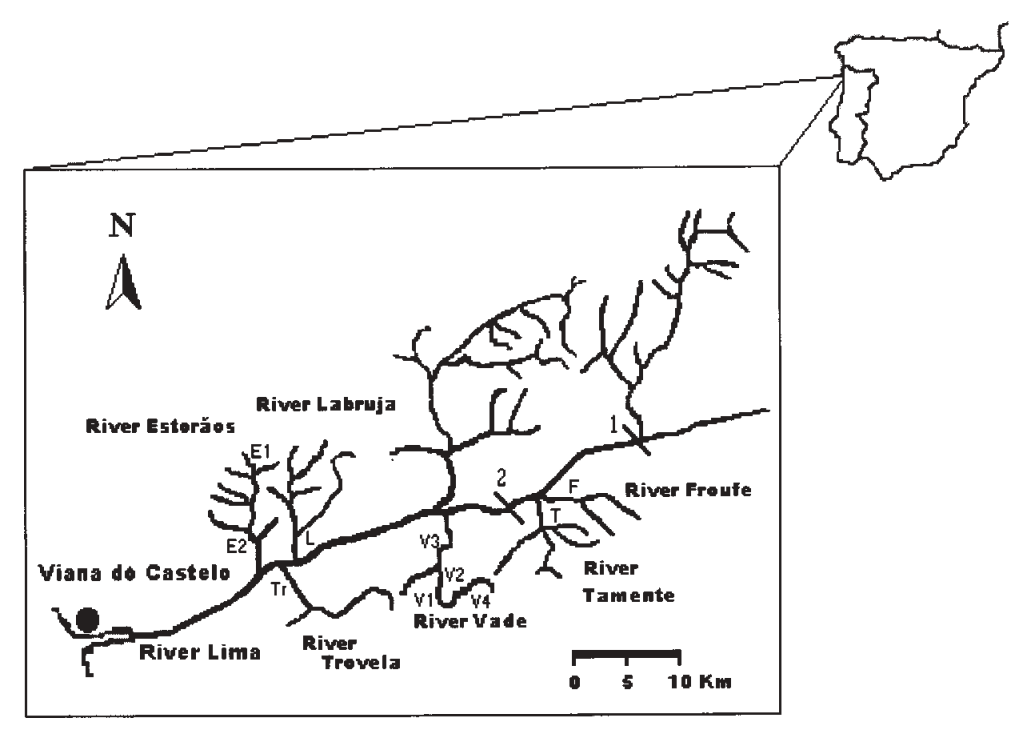

Figure 1. Location of the studied tributaries and the Alto Lindoso (1) and Touvedo (2) dams in the River Lima basin. Cuenca del rio Lima. Situación de los afluentes estudiados, asi como de los embalses de Alto Lindoso (1) y Touvedo (2). 
Estorãos (sites E1 and E2) and River Trovela (one site). One sample per year was collected from Rivers Labruja, Froufe and Tamente. Sampling reaches were $100 \mathrm{~m}$ in length, closed with stop nets. Two consecutive electrofishing runs were performed, except during unfavourable hydrological conditions. After the second sampling date, reaches $50 \mathrm{~m}$ upstream and downstream of each site-length were also fished once. All trout were anaesthetised (ethylenglycol-monophenylether, $2 \mathrm{ml} / 10 \mathrm{~L}$ water) and then measured (fork length, to the nearest $\mathrm{cm}$ ), weighed (grams fresh weight) and scales taken for age determination (Ombredane \& Baglinière, 1991). After recovering from anaesthesia, fish were released in the vicinity of the place where they were caught. Population density was estimated according to Moran-Zippin's method (Youngs \& Robson, 1978). Biomass estimates were obtained using Mohand linear relationship (Lobon-Cervia, 1991). Age was determined by scale reading, using the criteria refereed by Ombredane \& Baglinière (1991). The length-growth model was expressed by Von Bertalanffy growth curve (Bagenal \& Tesch, 1978). The length-weight relationship and the Fulton's condition factor were also calculated (Bagenal \& Tesch, 1978).

\section{RESULTS AND DISCUSSION}

\section{Diversity and spatial distribution of fish species}

Fish species present in the studied tributaries were brown trout (Salmo trutta), Iberian chub (Leuciscus carolitertii), Iberian roach (Rutilus arcasii), Iberian nase (Chondrostoma polylepis), Iberian barbel (Barbus bocagei), eel (Anguilla anguilla), three-spined stickleback (Gasterosteus aculeatus) and sea lamprey (Petromyzon marinus). All species were found at site E2 (River Estorãos). Trout smolts were caught at only this site, too.

Higher fish diversity was always observed at downstream sites. Brown trout population densities decreased downstream and cyprinids became the dominant fraction of the fish community, similarly to other European mountain Rivers (Lobon-Cèrvia et al, 1985; Baglinière \& Maisse, 1990; Rodrigues, 1995; Formigo, 1997).

Brown trout was the only species present at all sampling sites (Table 1), representing more than $50 \%$ of the total catch at upstream sites. These results agree with previous work in the Lima basin (Valente, 1990, 1993; Gonçalves, 1996), suggesting that trout is widespread in the basin of River Lima.

Tabla 1. Mean densities (ind/100 $\mathrm{m}^{2}$ ) of fish species present (brown trout, eel, Iberian chub, Iberian roach, Iberian nase, Iberian barbel, threespined stickleback and sea lamprey) at selected stretches of six tributaries of River Lima (i.e. Vade, Estorãos, Trovela, Labruja, Tamente and Froufe), caught between September 1995 and 1997. * present but not quantified due to the reduced number of fish caught. Densidades medias (ind/100 $\mathrm{m}^{2}$ ) de las especies presentes en las estaciones de muestreo de los afluentes del río Lima, durante el periodo de estudio. *especie presente pero imposible de cuantificar debido al bajo número de peces capturados.

\begin{tabular}{|c|c|c|c|c|c|c|c|c|}
\hline & $\begin{array}{c}\text { Brown } \\
\text { trout }\end{array}$ & Eel & $\begin{array}{l}\text { Iberian } \\
\text { chub }\end{array}$ & $\begin{array}{l}\text { Iberian } \\
\text { roach }\end{array}$ & $\begin{array}{l}\text { Iberian } \\
\text { nase }\end{array}$ & $\begin{array}{l}\text { Iberian } \\
\text { Barbel }\end{array}$ & $\begin{array}{c}\text { Three-spined } \\
\text { stickleback }\end{array}$ & $\begin{array}{c}\text { Sea } \\
\text { lamprey }\end{array}$ \\
\hline Vade 1 & 12.58 & 5.13 & & $*$ & $*$ & & & \\
\hline Vade 2 & 18.49 & 4.54 & 0.36 & & 1.19 & & & \\
\hline Vade 3 & 13.57 & 3.38 & 0.56 & 0.22 & 1.69 & 0.22 & & \\
\hline Vade 4 & 21.19 & & & 137.67 & & & & \\
\hline Estorãos 1 & 22.28 & 1.56 & 17.77 & & & & & \\
\hline Estorãos 2 & 3.37 & 24.78 & 15.78 & 8.15 & 1.27 & 1.26 & 5.00 & 0.98 \\
\hline Trovela & 18.70 & 5.28 & 1.50 & 29.89 & 2.96 & & 0.29 & \\
\hline Labruja & 27.94 & 2.92 & 3.58 & 7.58 & 3.57 & 4.12 & & \\
\hline Tamente & 18.51 & 13.36 & 4.32 & & 3.62 & & & \\
\hline Froufe & 7.19 & 10.11 & 12.92 & & 16.28 & 1.51 & & \\
\hline
\end{tabular}




\section{Population estimates and biomass}

The density of brown trout populations varied considerably within tributaries sampled. Lower densities were observed at site E2 and in the River Froufe, which are located downstream and are sites with a relative abundance of eel and cyprinid populations (Table 1). In the other studied tributaries and upstream of River Vade, mean estimated trout densities were in excess of $20 \mathrm{ind} / 100 \mathrm{~m}^{2}$. Trout occurred in higher numbers in upstream stretches of Rivers Vade and Estorãos (Table 1).

Seasonal fluctuations in density estimates were mainly related to changes in the range of juveniles (Fig. 2) and might be due to higher mortality rates typical during the first year of life (Elliot, 1994).

Except for site E2 (River Estorãos), we always observed that the $0^{+}$age group showed the highest density (Fig. 2). During summer and autumn, $0^{+}$was the dominant fraction of the brown trout population.
Mean biomass varied between $727.04 \mathrm{gFW} / 100$ $\mathrm{m}^{2}$ at site V4 and $23.04 \mathrm{~g} / 100 \mathrm{~m}^{2}$ at site E2. Despite the higher trout density estimated for River Labruja and for site E1 in River Estorãos, highest biomass values were observed in the River Vade (Table 2). These results are similar to those obtained for these tributaries in previous studies (Valente, 1990, 1993; Gonçalves, 1996).

Population density and biomass values fall within the range of values observed in other European Rivers (Lobon-Cervia \& Penczac, 1984; Lobon-Cervia et al., 1986; Crisp \& Beaumont, 1995), and are slightly higher to those observed in Rivers in Northern Spain (García de Jalón, 1988) and in the north of France (Maisse \& Baglinière, 1991).

\section{Age and growth}

Although age structure varied within any site, $0^{+}$ and $1^{+}$fish were the dominant age groups during summer and autumn, as a result of seasonal

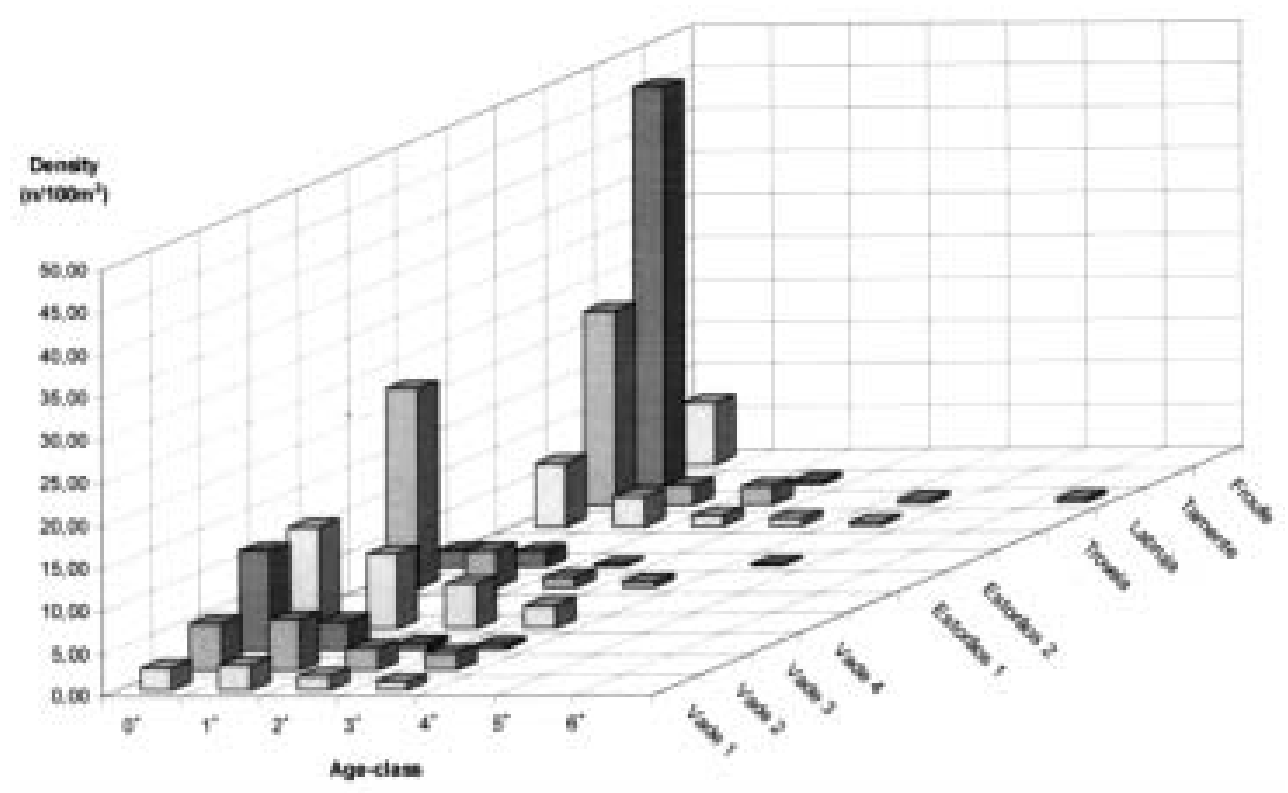

Figure 2. Mean estimated densities of brown trout populations (Salmo trutta) in the studied tributaries of River Lima, grouped by age-class. Densidades medias estimadas de las poblaciones de trucha, agrupadas por clases de edad en los afluentes del río Lima. 
Tabla 2. Mean biomass values $\left(\mathrm{gFW} / 100 \mathrm{~m}^{2}\right.$ ) of fish species present (brown trout, eel, Iberian chub, Iberian roach, Iberian nase, Iberian barbel, three-spined stickleback and sea lamprey) in study sites of 6 tributaries of the River Lima, caught between September 1995 and 1997 * present but not quantified due to the reduced number of fish caught. Biomasas medias $\left(\mathrm{gFW} / \mathrm{m}^{2}\right)$ de las especies presentes en las estaciones de muestreo de los afluentes del río Lima durante el periodo de estudio. * especie presente pero imposible de cuantificar debido al bajo número de peces capturados.

\begin{tabular}{|c|c|c|c|c|c|c|c|c|}
\hline & $\begin{array}{c}\text { Brown } \\
\text { trout }\end{array}$ & Eel & $\begin{array}{l}\text { Iberian } \\
\text { chub }\end{array}$ & $\begin{array}{l}\text { Iberian } \\
\text { roach }\end{array}$ & $\begin{array}{l}\text { Iberian } \\
\text { nase }\end{array}$ & $\begin{array}{l}\text { Iberian } \\
\text { Barbel }\end{array}$ & $\begin{array}{c}\text { Three-spined } \\
\text { stickleback }\end{array}$ & $\begin{array}{c}\text { Sea } \\
\text { lamprey }\end{array}$ \\
\hline Vade 1 & 393.20 & 261.76 & & $*$ & $*$ & & & \\
\hline Vade 2 & 661.99 & 193.91 & 20.11 & & 56.29 & & & \\
\hline Vade 3 & 391.66 & 174.59 & 14.56 & 0.88 & 42.08 & 18.38 & & \\
\hline Vade 4 & 727.04 & & & 903.11 & & & & \\
\hline Estorãos 1 & 187.45 & 50.87 & 272.84 & & & & & \\
\hline Estorãos 2 & 23.04 & 165.65 & 110.61 & 37.03 & 56.26 & 47.43 & 2.45 & 10.25 \\
\hline Trovela & 355.18 & 250.66 & 42.02 & 190.19 & 40.70 & & 0.19 & \\
\hline Labruja & 617.50 & 67.85 & 52.15 & 56.76 & 136.96 & 368.17 & & \\
\hline Tamente & 132.55 & 1120.65 & 75.10 & & 6.71 & & & \\
\hline Froufe & 41.43 & 560.03 & 108.65 & & 368.41 & 57.15 & & \\
\hline
\end{tabular}

recruitment. Populations with similar age-structure have been found in other European salmonid Rivers (e.g. Lobon-Cervia et al., 1986; Maisse \& Baglinière, 1990, 1991; Champigneulle et al., 1991; Elliott, 1994).

Rivers Vade and Labruja presented the widest range in age-classes. Although some $6^{+}$and $7^{+}$ trout were caught, $4^{+}$and older individuals were scarce and their presence was detected especially in winter. In Rivers Tamente and Froufe, only

Tabla 3. Length-weight relationship parameters and mean Fulton's condition factor $(\mathrm{K})$ for all fishes (brown trout, eel, Iberian chub, Iberian roach, Iberian nase, Iberian barbel, three-spined stickleback and sea lamprey) present in each of the six studied tributaries of River Lima (i.e. Vade, Estorãos, Trovela, Labruja, Tamente and Froufe). Relaciones longitud-peso para todos los afluentes del río lima estudiados, así como la media del factor de condicion de Fulton (K).

\begin{tabular}{lrrrrr}
\hline & Log a & b & r & N & K \\
\hline Vade & -4.19 & 2.92 & 0.99 & 1008 & 1.22 \\
Estorãos & -4.29 & 2.93 & 0.99 & 646 & 1.25 \\
Trovela & -4.31 & 2.94 & 0.99 & 524 & 1.19 \\
Labruja & -4.43 & 2.99 & 0.99 & 122 & 1.16 \\
Tamente & -4.44 & 3.00 & 0.99 & 93 & 1.17 \\
Froufe & -4.39 & 2.95 & 0.99 & 21 & 1.13 \\
\hline
\end{tabular}

few trout which were $1^{+}$and older, were found. As these sites are near the confluence with the Touvedo reservoir and have good spawning areas, these Rivers it is suggested are being used by the older trout present in the Touvedo reservoir (Valente et al., 1995; Cruz, 1998).

Growth was isometric (Table 3) and only small differences were detected between sites. Our data agree with those of other authors in the same streams (Valente, 1993; Gonçalves 1996), in the River Âncora (Formigo, 1997), and in other Iberian Rivers (Lobon-Cervia \& Penczac, 1984; Garcia de Jalón et al., 1986; Braña et al., 1992; Rodrigues, 1995; Gonçalves, 1996) and northern European Rivers (Egglishaw \& Shackley, 1977; Moreau \& Abad, 1987; Crisp \& Beaumont, 1995).

Fulton's condition factor $(\mathrm{K})$ is generally good and shows similarity between all sites (Table 3 ).

Although growth was slightly higher in River Vade, back-calculation based on scale-reading showed that trout growth may have been slow in all tributaries (Table 4 and Fig. 3). These results are consistent with those obtained for unproductive waters (Lobon-Cervia et al., 1986; Garcia de Jalón et al., 1986; Moreau \& Abad, 1987; Maisse \& Baglinière, 1990; Crisp \& Beaumont, 1995; Rodrigues, 1995; Formigo, 1997). 


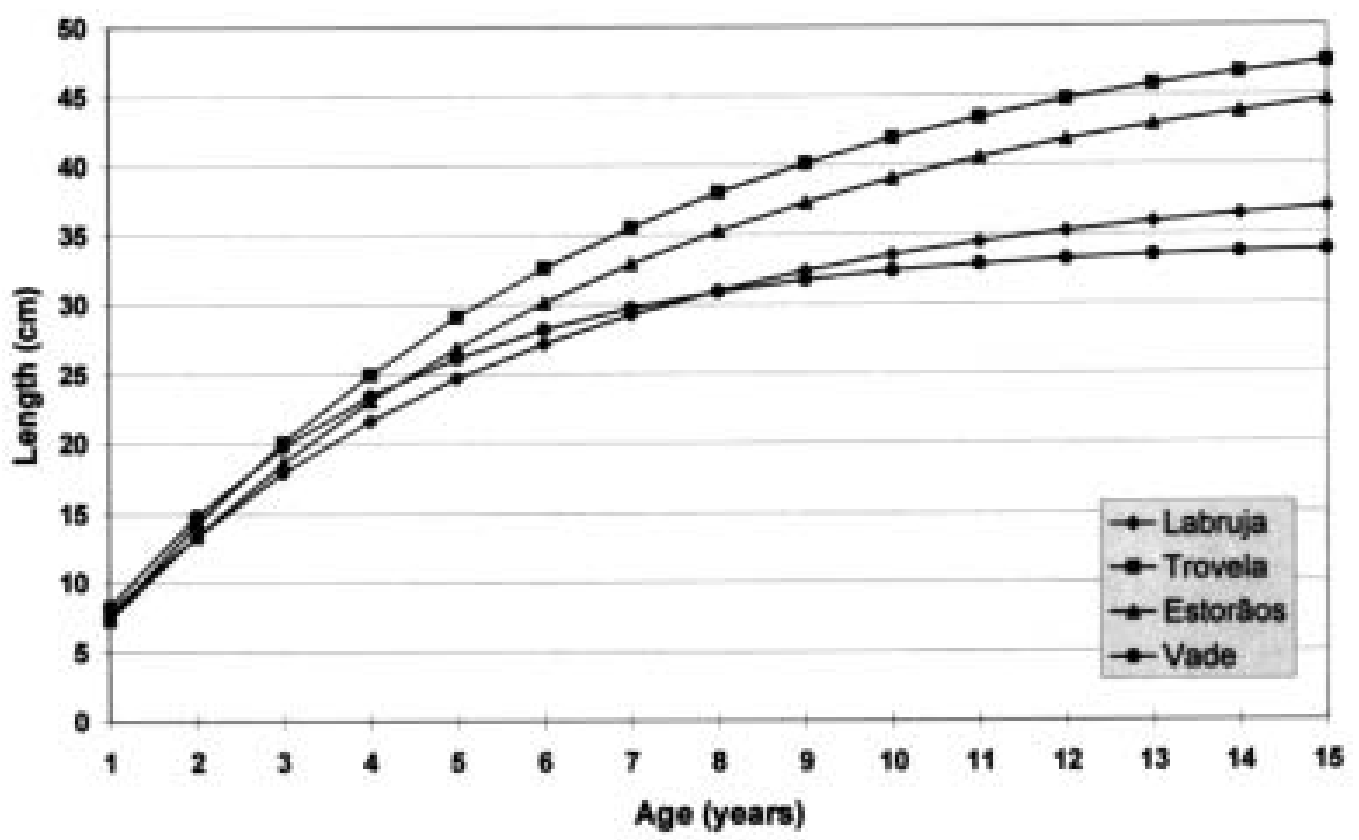

Figure 3. Von Bertalanffy growth curves for brown trout (Salmo trutta) populations in studied tributaries of River Lima. Curvas de crecimiento de Von Bertalanffy para las poblaciones de truchas.

Tabla 4. Von Bertalanffy growth equation parameters for brown trout populations (Salmo trutta) across sites studied. $\mathrm{K}$ - growth rate; $\mathrm{L}_{\infty}$ - maximum size; $\mathrm{t}_{0}$ - time scaler equivalent to the (hypothetical) starting time. Parametros de la ecuación de crecimiento de Von Bertalanffy para las poblaciones de trucha. $K$ - tasa de crecimiento; $L_{\infty}$ - talla máxima; to - medida temporal equivalente al tiempo de inicio (hipotético).

\begin{tabular}{lccr}
\hline & $\mathbf{K}$ & $\mathbf{L}_{\infty}$ & \multicolumn{1}{c}{$\mathbf{t}_{\mathbf{0}}$} \\
\hline Vade & 0.290 & 34.26 & 0.04 \\
Estorãos & 0.157 & 49.28 & -0.03 \\
Trovela & 0.169 & 51.62 & 0.08 \\
Labruja & 0.194 & 38.91 & -0.17 \\
\hline
\end{tabular}

\section{CONCLUSIONS AND MANAGEMENT RECOMMENDATIONS}

The brown trout populations in the basin of the River Lima (Northwest Portugal) provide an important recreational fishery (Valente \& Alexandrino, 1990). Information is needed on the populations dynamics, growth and production of this species for its conservation and management (Hellawell, 1976; Welcomme, 1995; Cowx \& Welcomme, 1998).

Trout populations in the studied tributaries of the River Lima do not differ markedly from those in other, comparable European areas (LobonCervia et al., 1986; Maisse \& Baglinière, 1990, 1991; Gonçalves, 1996; Formigo, 1997). Densities observed here can probably be considered normal of mountain streams.

The studied tributaries of River Lima had good spawning and nursery areas, as evidenced by the high number of $0^{+}$and $1^{+}$trout present in sampled stretches.

The effects angling is having on brown trout populations were not evaluated. However, preliminary data suggest angling pressure is not having a significantly negative impact on this species. Effective angling surveillance and a more precise catch declaration system are essential to allow correct evaluation of angling pressure and impacts. 
Special attention should also be directed to restocking actions with a view to the conservation of the native brown trout populations. The effects of re-stocking have not been evaluated yet, either. Recently, genetic analyses of trout populations of the Lima basin (Antunes, 1997), and studies of the movements of the brown trout in the River Vade (Maia, 1998) have suggested that re-stocking is inefficient and that populations of brown trout in the River Vade are self-sustaining.

\section{ACKNOWLEDGEMENTS}

The data presented are part of the Project PRAXIS XXI 3/3.2/BIA/41/94, Biology and Ecophysiology of the Northern Portuguese Salmonid Populations. We are grateful to the Direcção Regional de Agricultura de Entre Douro e Minho for their co-operation. Thanks to Nuno Barros, Mónica Mendes, António Sá Pereira and António Pereira for their help during field work.

\section{REFERENCES}

ANTUNES, A. P. 1997. Caracterização genética de algumas sub-populações de truta-de-rio, Salmo trutta L., da bacia hidrográfica do rio Lima. MSc. Thesis, Universidade do Porto, 92 pp..

BAGENAL, T. B. \& F. W. TESH. 1978. Age and growth. In: Methods for the Assessment of Fish Production in Fresh Waters. Bagenal, T.B., (ed.): 101-136. IBP Handbook, 3. Blackwell, Oxford.

BRAÑA, F., A. G. NICIEZA \& M. M. TOLEDO. 1992. Effects of angling on population structure of brown trout, Salmo trutta L., in mountain streams of Northern Spain. Hydrobiologia, 237: 61-66.

CHAMPIGNEULLE, A., B. BITTIKER, P. DURAND \& M. MELHAOUI. 1991. Principales caractéristiques de la biologie de la truite (Salmo trutta L.) dans le Léman et quelques affluents. In: La Truite: Biologie et Écologie. Baglinière, J. L. \& G. Maisse (eds.): 153-182. INRA Editions, Paris.

CRISP, D. T. \& W. R. C. BEAUMONT. 1995. The trout (Salmo trutta) population of the Afon Cwm, a small tributary of the Afon Dyfi, mid-Wales. J. Fish Biol., 46: 703-716.
CRUZ, M. J. 1998. Contributo para o ordenamento das albufeiras de Alto Lindoso e Touvedo (bacia hidrográfica do rio Lima). MSc. Thesis, Universidade do Porto, $130 \mathrm{pp}$.

EGGLISHAW, H. J. \& P. E. SHACKLEY. 1977. Growth, survival and production of juvenile salmon and trout in a Scottish stream 1966-75. J. Fish Biol., 11: 647-672.

ELLIOTT, J. M. 1994. Quantitative Ecology and the Brown Trout. Oxford Series in Ecology and Evolution, Oxford Univ. Press, 286 pp.

FORMIGO, N. M. E. 1997. A bacia hidrográfica do rio Âncora - caracterização ecológica e potencialidades bio-económicas para a práctica da pesca desportiva. $\mathrm{PhD}$ Thesis, Universidade do Porto, $500 \mathrm{pp}$.

GARCIA DE JALÓN, D., C. MONTES, E. BARCELO, C. CASADO \& F. MENES. 1988. Effects of hydroelectric scheme on fluvial ecosystems within the Spanish Pyrenees. Regulated Rivers: Research and Management, 2: 479-491.

GONÇALVES, F. 1996. Ictiofauna do PNPG. Inventário das populações, do habitat e proposta de normativo para a pesca desportiva. MSc. Thesis, Universidade do Porto, 104 pp.

LOBÓN-CERVIÁ, J. \& T. PENCZAC. 1984. Fish production in the Jarama River, central Spain. Holoartic Ecology, 7: 128-137.

LOBÓN-CERVIÁ, J., C. MONTAÑÉS \& A. SOSTOA. 1986. Reproductive ecology and growth of a population of brown trout (Salmo trutta L.) in an aquifer-fed stream of Old Castile (Spain). Hydrobiologia, 135, 81-94.

LOBÓN-CERVIÁ, J. 1991. Dinamica de poblaciones de peces en rios. Pesca eléctrica y métodos de capturas sucessivas en la estima de abundancias. Monog. Mus. Nac. Ciencias Naturales, Madrid, 156 pp.

MAIA, C. F. Q. 1998. Potencialidades do rio Vade para a recuperação da população de salmão, Salmo salar, da bacia hidrográfica do rio Lima. MSc.Thesis, Universidade do Porto, 72 pp.

MAIA-MENDES, M. 1997. Rio Minho um século de repovoamentos com salmonídeos. I Simpósio Ibérico sobre a bacia hidrográfica do rio Minho, 85-88.

MAISSE, G. \& J. L. BAGLINIÈRE 1990. The biology of brown trout, Salmo trutta L., in the River Scorff, Brittany: a synthesis of studies from 1973 to 1984. Aquaculture and Fisheries Management, 21: 95-106.

MAISSE, G. \& J. L. BAGLINIÈRE. 1991. Biologie de la truite commune (S. trutta) dans les riviéres françaises. 
In: La Truite: Biologie et Écologie. Baglinière, J. L. \& G. Maisse (eds.): 25-45. INRA, Paris.

MOREAU, J. \& N. ABAD. 1987. Mise en évidence des différences de croissance entre individus sauvages et introduits chez la truite, Salmo trutta. Annls Limnol., 23 (3): 253-261.

OMBREDANE, D. \& J. L. BAGLINIÉRE. 1991. Les ecailles et leurs utilisations en ecologie halieutique. In: Tissus Durs et Âge Individuel des Vertébrés. Bagliniere, J. L., J. Castanet, F. Conand \& J. Meunierl. (eds.): 151-192. INRA, Paris.

RAMOS, M. A. 1982. Atlantic salmon ranching in Portugal. In: Sea Ranching of Atlantic Salmon. Erikssson, C., M. P. Ferranti \& P.O. Larsson (eds.): 109-125. Commission of the European Communities, Cost 46/4 Workshop.

RODRIGUES, L. S. B. 1995. Parâmetros populationais da fauna piscícola e uso do habitat por Salmo trutta L. num rio de montanha (Rio Ôlo, Parque Natural do Alvão). MSc. Thesis, Universidade do Porto, 162 pp.

VALENTE, A. C. N. \& P. J. B. ALEXANDRINO. 1990. A ictiofauna do rio Lima. Alguns aspectos sobre a sua exploração e conservação. Actas $1^{\circ}$ Simpósio sobre a Protecção e Revalorização da Faixa Costeira do Minho ao Liz, 37-42.

VALENTE, A. C. N. 1990. Trout populations in the Lima basin, North Portugal. In: Management of Freshwater Fisheries. Van Densen, W. L., T. B. Steinmetz \& R. H. Hugues (eds.): 437-446. Proc. Symp. EIFAC, Sweden.

VALENTE, A. C. N. 1993. Biologia e dinâmica das populações de truta de rio (Salmo trutta L.) da bacia hidrográfica do rio Lima. $\mathrm{PhD}$ Thesis, Universidade do Porto, $244 \mathrm{pp}$.

VALENTE, A. C. N., F. GONÇALVES \& C. MAIA. 1995. Controle do dispositivo de transposição da barragem de Touvedo - Resultados preliminares sobre a comunidade íctica do rio Lima. Congresso Nacional de Conservação da Natureza Ecossistemas Ribeirinhos, 144-151.

YOUNGS, W. D. \& D. S. ROBSON. 1978. Estimation of the population number and the mortality rates. In: Methods for the Assessment of Fish Production in Fresh Waters. Bagenal, T.B. (ed.): 137-164. IBP Handbook, 3. Blackwell, Oxford. 